\title{
The Impact of Financial Innovation Investment Support on SME Competitiveness
}

\section{- Anna Lewandowska, Yuriy Bilan, Grzegorz Mentel}

\begin{abstract}
This article examines financial support (especially EU Structural Funds as the main tool of cohesion policy) for investments as a lever for the development of SME innovativeness in Poland. The European Commission strongly stresses the importance of their cohesion policy and support for SMEs. European enterprises have suffered significantly from the credit crunch, and the situation could worsen as banks engage in restructuring to eliminate impaired assets from their balance sheets. Supporting SMEs and promoting entrepreneurship is essential for economic development and competitiveness, especially in less developed regions. The main aim of this study is to establish the impact of financial support for investments, especially from EU Structural Funds, on SME competitiveness in Poland. We have analyzed empirically the data drawn from CATI carried out among 805 firms. We have learned how SMEs assess the financial support from different sources along with the resulting impact on the competitiveness of SMEs. The main statistical test for relationships and dependencies was the chi-square independence test and Cramer's V. The results of our research show that SMEs have not used financial support efficiently. Moreover, micro-enterprises were shown to be the least effective after receiving financial support from EU funds. This support often has a demand-driven effect, but it does not improve firm competitiveness.
\end{abstract}

Keywords: investments in innovation, EU funds, economic growth, competitiveness, SMEs JEL Classification: L11, L25, O31, R11

Received: December, 2020

1st Revision: June, 2021

Accepted: June, 2021

\section{INTRODUCTION}

Despite the growing role of small and medium-sized enterprises, in Poland this sector only accounts for a small share of the economy compared to the EU average. This finding is echoed in the performance of the SME sector, which shows a lower share for SMEs in sales revenues and productivity than the EU average (PARP, 2011-2013; Ministerstwo Gospodarki, 2014). The development potential of SMEs has not been fully realized due to the lack of capital to finance such enterprises (PARP, 1997-2013). Therefore, finding the most effective means of financial 
support for SMEs, which is essential for achieving economic development, is crucial. Supporting SMEs in an economically underdeveloped region might be considered one of the most effective pro-development factors. In this perspective, it is necessary to support business development in these regions and in less developed countries, thus affecting the competitive position of SMEs as well as increasing employment, tax bases and regional development (Lewandowska et al., 2019). SMEs have displayed a lack of capital for current investments to a greater extent than have large businesses. Insufficient access to external financing is a significant barrier to the development of enterprises, especially for start-ups and those pursuing innovative investments. Supporting small and medium-sized enterprises is considered one of the best ways to activate regions, especially within the range of "economic growth, job creation and economic and social cohesion” (Vojtovič, 2016; European Commission, 2010a). EU efforts for SMEs in the years 2004-2006 and 2007-2013 were based mainly on the support and promotion of entrepreneurship with the goal of creating an environment that supports innovation and competitiveness and thus enhancing market access for businesses.

Many contemporary empirical studies and most economic growth theories recognize the importance of innovation as one of the most progressive determinants of socio-economic growth (Audretsch et al., 2014). A high firm-level of innovativeness has a positive impact on productivity at the firm level (business performance, see e.g. Squicciarini, 2017). In the modern global economy, competitiveness is the basic mechanism of development, with innovativeness one of the ways of achieving higher rates. Competitiveness conditioned by innovativeness and continuous technological advancement is a challenge for countries and regions that want to develop.

Studies on the effectiveness of financial instruments for SMEs, especially the Polish national analysis, have focused primarily on documents relating to EU programs. In addition, very few of these investigations analyze large sets of data at the micro-level which describe SME competitiveness. Many questions remain unanswered. What is the extent of reducing economic and social differences between regions as a result of EU funds? What is the impact of financial support addressing SMEs to reduce regional disparities? What is the net efficiency of financial instruments used within the framework of the European Union's policy on SMEs? What importance does the use of funds from EU funds have for SME competitiveness? In this article we will try to answer the second of these questions. The general aim of our research is to explore the effectiveness of financial support of investments in innovation and their impact on SME competitiveness (i.e. whether the drawing of financial support had an impact on the involvement of SMEs in investments in innovation, and whether the financial support contributed to improving competitiveness). Related to this aim are two crucial questions. Firstly, how do the owners or managers of SMEs assess the effectiveness of their investment in innovation? Secondly, are there any differences in the evaluation of innovation effectiveness among the various sizes of businesses? The authors have investigated the effects of innovation (with financial support and without financial support) activities not only among small and medium entities but also microfirms, which are not covered in official innovation surveys by the national statistical offices. Our research is based on data drawn from CATIs carried out among 805 firms (209 firms that received financial support and 596 firms which did not receive financial aid). We hope to make 
a conceptual contribution to knowledge concerning innovation activity as well as the role of financial support in innovation activity.

The article is organized as follows. The first section of the paper presents a literature review on the financial support of investment in innovation and aspects related to competitiveness, highlighting connections and the impact of a number of investments on competitiveness and the possibility of joint examinations. In the second section, the authors present the description of the methods and data used; the third section consists of the presentation and discussion of the results. The paper ends with concluding remarks.

\section{THEORETICAL BACKGROUND}

In the global economy, innovations are perceived as a way of overcoming difficulties as well as ensuring and preserving economic growth. Innovation can play a significant role in seeking out new sustainable sources of growth and competitiveness in cases where innovativeness is a central goal of economic policy (Galbraith et al., 2017). A permanent competitive advantage can be achieved primarily by growing innovative potential. The introduction of new, significantly improved products, processes and methods is becoming crucial to productivity as well as job creation. Various concepts and perspectives have been put forth as to what makes activities innovative and what stimulates them as well as on the effects of specific innovations. Lewandowska et al. (2019) have examined how EU economic policy instruments influence the innovation of enterprises within the context of the Regional Innovation System. According to this study, enterprises use only specific public policy instruments; business demand for innovation-supporting instruments changes in reaction to business cycle phases and financial incentives. During periods of economic expansion, companies increase innovation, while during contractions innovation decreases or even stops altogether. Kokot-Stępień \& Krawczyk (2020) found no significant impact of public support on the innovative activity of enterprises. According to Florio et al. (2017), the most effective strategies to support SME innovation are represented by those more ambitious instruments that have a well-specified logical intervention, focused objectives, and selective targeting strategies. Previously, Smith \& Waters (2011) as well as Melnikas (2008) demonstrated the need for horizontal networks among firms, institutional systems of vocational training as well as substantial public and private investment in innovation.

An investment in innovation is a financial outlay that creates the basis for instituting or increasing innovative projects for which it is implemented or that contributes to the implementation of new products, processes or organizational solutions (Oslo Manual, 2005; PARP, 2007). Prior to project implementation, this investment can also represent the following types of activities: (1) Investments in machinery and equipment; (2) Investments in intellectual property; (3) Investments in knowledge. While it has been well-established that competitiveness as a concept has been defined in numerous ways, in general terms, competitiveness is simply about continuous existence or "surviving" in the marketplace. To be able to do so, a special ability to maintain and enhance market shares is required (Leal Filho \& Weresa, 2007). Competitiveness should also reflect the changing needs and preferences of user groups and may involve providing the highest quality products and services at the lowest possible price. According to the Oslo Manual (2005), 
competitive advantage is achieved by improving the company's ability to become and remain innovative by enhancing the ability to develop new products or processes as well as by increasing and creating new knowledge.

Investments in innovative undertakings seek to increase the level of competitiveness of enterprises through the application of new solutions (Juris et al., 2021; Lewandowska, 2021). Currently, the main sources of competitive advantage of enterprises operating in Poland rely on low labor costs and the large domestic market. In terms of development trends and advanced globalization, however, sustainable growth can only be guaranteed by enhancing competitive advantages based on innovative solutions. This means that enterprises that wish to be(come) competitive internationally should invest in the latest solutions to strengthen their competitive position in the market (Braja \& Gemzik-Salwach, 2019). This mainly includes the involvement of entrepreneurs pursuing activities in the field of R\&D. Consequently, public intervention with the support of EU funds has focused on support for undertakings related to the development, implementation and transfer of technologically and organizationally innovative solutions (Ministry of Regional Development, 2011; European Commission, 2010b).

A diagnosis of the economic situation reveals that entrepreneurs are unwilling to invest in innovative projects characterized by risks that carry relatively high exposure over extended periods of time (Juris et al., 2021). This means that there is a severe gap between perceived cost/benefit-risk- and time-horizons for available investment capital. Consequently, it is often impossible to acquire capital for endeavors that may carry higher risk, the consequences for which limit investment to short-term projects that yield relatively low value. This is notably the case for otherwise, highly innovative SMEs that are nevertheless in their early stages of growth. Therefore, public intervention is justified in these cases, as public intervention can increase investment levels toward innovative solutions that offer the public both economic and technological benefits (Kokot-Stępień \& Krawczyk, 2020). Likewise, due to the insufficient number of innovative start-up enterprises, it is necessary to offer incentives that support the establishment of companies founded upon innovative ideas.

Supporting innovation, particularly technological progress, is considered a substantial element of policies towards sustainable development (Nill \& Kemp 2009) and competitiveness maintaining (Tvaronaviciene \& Burinskas, 2020; Braja \& Gemzik-Salwach, 2019; Bednář \& Halásková, 2018; Ilyash et al., 2018;). It is considered that both research and innovation contribute to employment growth, increased prosperity and quality of life (Ramstad, 2009), mainly due to highly skilled employees retaining (Bilan et al., 2020) and positive changes in income distribution in developed countries. Given the above assumptions and the role of research in the knowledge-based economy, the European Union has decided to create its innovative policies and instruments of implementation. The particular importance of the innovation policy of the European Union was expressed in the new EU Strategy Europe 2020 Strategy for smart, sustainable and inclusive growth (European Commission, 2010b), to which cohesion policy refers since 2010.

EU Structural Funds have been identified as the most important tool of regional policy within the concept of economic and social cohesion and the primary tool for supporting the development of SMEs. Additionally, the ERDF has a mission to correct significant spatial imbalances in EU countries and regions and increase growth potential by supporting structural adjustment 
in lagging regions and the reconversion of declining industrial regions (Berkowitz et al., 2020; Hagen \& Mohl, 2010; Lolos \& Sarantis, 2009). From the moment of Polish accession to the EU (in the programming period 2004-2006 and 2007-2013), the main source of finance for SMEs in Poland from the EU funds was the Sectoral Operational Programme Improvement of the Competitiveness of Enterprises for 2004-2006 and Operational Programme Innovative Economy for 2007-2013.

Studies on the effectiveness of the mechanisms and instruments on the convergence process have presented mixed findings. For example, Hagen \& Mohl (2008), who investigated the efficacy of European cohesion policy in reducing regional welfare differences, observed a negligible impact of cohesion policy on convergence. On the other hand, Eckey \& Türk (2006) find a significant positive impact of EU funds and slight regional convergence. They recommended EU Structural Funds should be focused on human capital and innovative activities.

The impact of EU financial support on social-economic integration and improvement of living conditions in Poland is evaluated similarly in the works of Misiag et al. (2013), Wojarska (2016), or Murzyn (2020). These authors show studies of the effectiveness of using the EU support in Poland and indicate some recommendations. They analyze the impact of EU support on achieving the main objective of the national strategic reference framework and National Development Strategy. The analysis shows that EU funds are unevenly distributed and the impact of the Funds on convergence is ambiguity. The impact of structural funds was weaker than expected. While the cohesion policy is assessed rather positively, some authors are more critique in terms of its effectiveness. Bachtler \& McMaster (2008) question the notion that the Structural Funds build to the development of regional structures. They believed there is no guarantee that the Structural Funds promote regionalization, at least in the short to medium terms.

The assessments of the effectiveness of financial instruments under the cohesion policy, at the Polish national analysis, especially at the SME level, focused primarily on the programming documents, strategic documents, studies and researches signed by business development authorities (Murzyn, 2020; Misiag et al., 2013). However, almost none of them analyze large micro data sets related to indicators of economic development, economic productivity and SME competitiveness.

An example of a study with a microeconomic approach to the analysis and assessment of the effectiveness of EU financial instruments is the one of Bernini \& Pelegrini (2011). They found out that companies with subsidies compared to non-subsidized firms have a higher volume of production, employment, and fixed assets but a lesser increase in Total Factor Productivity. In addition, labor productivity had decreased in the subsidized companies. Studies on the effectiveness of financial support from EU funds that used similar methodology are scarce (e.g., Vojtovič, 2016; Bondonio, 2014; Bernini \& Pelegrini, 2011). To the authors' best knowledge, there is no analysis of the effectiveness of financial support from the Structural Funds following the aims of several programs, e.g., the Sectoral Operational Programme Improvement of the Competitiveness of Enterprises for 2004-2006, Operational Programme Innovative Economy for 2007-2013, and Operational Programme Human Capital for 2007-2013 and so on. This means that a study should be carried out identifying and assessing the effects of EU Structural Funds on SME competitiveness based on their commitment to research and innovation, ICT, intellectual property protection, or the implementation of new solutions. 


\section{AIM, METHODOLOGY AND DATA}

The main aim of this study is to evaluate the financial support for investments, especially from the EU funds, and its impact on growth and SME competitiveness in Poland. The following hypothesis was formulated:

H1. Financial support for innovation investments is ineffectively used by SMEs. Financial support from the EU funds does not improve the competitiveness of SMEs.

H2. The financial support effectiveness evaluation from the EU funds changes with the size of the enterprise.

The analysis is based on a questionnaire from the project titled "The Study of the Impact of Investments in Innovation on the Competitiveness of the SME Sector in Podkarpackie Region", which was conducted in the years 2014-2015, financed within the statutory means of UITM (University of Information Technology and Management in Rzeszów). The questionnaire included 232 variables (mainly on a nominal and ordinal scale), but the following 58 variables were constructed for the analysis presented in this paper. The research was very complex and sophisticated, so the analysis of all data and publication of results took a few years. Despite this, the validity of our results is enormous because the study addressed several new and problematic issues in the financial support for innovation context and SME competitiveness, i.e., to evaluate different EU programs, long period of support, and many types of economic results. The sample selection in the survey was carried out by a stratified sampling method according to the size of the enterprise (number of employees) and its sector (NACE rev. 2 section, please see: Eurostat 2008). The research was based on data drawn from CATIs carried out among 805 firms. The sampling criteria were rendered according to GDP contribution. We used the method of a structured computer-assisted telephone interview (CATI) method. The research focused on the effectiveness of innovation activity in SMEs. This research studied the impact of financial innovation investment support on the growth of SMEs as one of several drivers in the innovation activity.

The importance of the financial support was examined, especially the EU funds for growth and competitiveness of SMEs based on the assessment of experts (i.e., owners or managers of the companies). This method of research is one of several standard methods in the system of microeconomic approaches to this issue. This method completes analyses based on macroeconomic indicators or financing data. These persons usually prepare project proposals to receive financial support and have knowledge of using these financial resources in a particular company. The result of this assessment may be more appropriate and accurate than an evaluation based on financing data. One issue should be noted. The information value of these interviews and data obtained is independent and is not assessed based on the statistical number of interviews. The object of an empirical study was a suitably selected research sample of the research group of 805 SMEs (209 enterprises which obtained financial support - treated group) and 596 enterprises which did not obtain financial support - control or comparison group) (Cera et al., 2020). Our research sample included micro, small and medium enterprises. The sampling criteria were rendered according to official statistics, i.e., more than $79 \%$ of microenterprises are individual entrepreneurs, and the rest employ 1-49 workers. The big question is "What were the 
results in your company caused by the investment activities in 2004-2013 and did they affect the functioning of the company to a large, medium or small extent? (Indicate its significance by you: small, medium, and large or did not occur or I don't know)." This question was a closed question of the structured interview. Table 1 demonstrates information on the numbers of examined enterprises and the assessment of results. The number of evaluations means the number of replies in particular economic results (the entrepreneur could choose more than one answer in specific economic results - see Table 2 for the exact number).

Tab. 1 - The number of examined enterprises and assessment of results. Source: own research

\begin{tabular}{|l|l|l|l|l|l|l|}
\hline \multirow{2}{*}{ Enterprise groups } & \multicolumn{3}{|l|}{ Treated group } & \multicolumn{3}{l|}{ Control group } \\
\cline { 2 - 8 } & Micro & Small & Medium & Micro & Small & Medium \\
\hline $\begin{array}{l}\text { The number of enterprises } \\
\text { (and interviews) }\end{array}$ & 109 & 45 & 55 & 388 & 85 & 123 \\
\hline The number of evaluation & 569 & 256 & 447 & 1449 & 338 & 934 \\
\hline
\end{tabular}

The chi-square test of independence and Pearson's correlation coefficient with a significance level of $5 \%$ was used in the analysis of statistical relationships and differences between the responses of the respondents in financially supported and without financially supported enterprises. To arbitrate the strength of dependence between the variables, Cramer's V was implemented. Due to the nominal character of the variables, Cramer's $\mathrm{V}$ was used to determine the association between them.

\section{RESULTS AND DISCUSSION}

The aim and support areas of the Sectoral Operational Program Improvement of the Competitiveness of Enterprises 2004-2006 and Operational Program Innovative Economy 2007-2013 was based on challenges and development needs in the area of R\&D\&I, which were indicated in the Lisbon Strategy, the Community Strategic Guidelines (CSGs), and the Polish National Strategic Reference Framework (NSRF). They assess the effectiveness of financial resources from the Structural Funds in enterprises, referring to the main goal - increasing competitiveness. These concerned mainly an increase in production flexibility and efficiency, company market share, new markets, an increase in revenues, creation of new market structures, job creation, growth of rank of an improved product or service among other products, improved quality of improved product or service in the eyes of customers, investments in the growth of SMEs and investments in sustainable job creation (European Commission, 2008).

Some of these factors may suggest increasing SME competitiveness, but this is not a cause for this. For example, an increase in revenues, improving the quality of a product, or job creation may indicate increasing competitiveness if its source is the labor productivity growth, the improved production efficiency, or the introduction of a new production process, and so on. At the same time, an increase in revenues, improving the quality of a product, or job creation may be the effect of using more factors of production. Still, it does not necessarily lead to the growth of labor productivity or increased competitiveness. 
Investments in innovations of the surveyed enterprises included investment on machinery and equipment, on ICT, on intellectual property protection, on training, on marketing activities, and implementation of new solutions. The economic activity indicators of enterprises, as potential responses in our study, were considered activities that improve productivity, profit and thus enhanced competitiveness of the enterprise itself in the short and especially in the long term (Lewandowska, 2021). These are mostly an improved product or service among other products, company market share, production flexibility, production efficiency, labor costs, amount of materials and energy, operating costs, sources of supply, and new market structures. The growth of production, revenues, prices of products, share in the market, or creation of new jobs are significant results of investment activity. Still, these are not the cause behind improved SME competitiveness and its sustainability. This proves our H1. In Table 4 in the Appendix, we show the chi-square test and Crammer's $V$ results. Table 4 shows how financial support tools were related to economic effects and improving SME competitiveness.

Unsupported enterprises have more economic effects at a statistical significance level in comparison to supported enterprises. In firms that received financial support, there are only the following: improving production flexibility, new sources of supply were developed, suppliers have not adapted to new or changed materials and services, increasing work safety, increasing work standards, and creation of new jobs. The same economic effects in unsupported enterprises have smaller values than in supported enterprises. From Table 4, it is clear that detailed economic effects differed according to the dependence between variables and strength of this dependence. We have observed there is a weak dependence between variables ( $\phi_{\mathrm{c}}$ from 0.1 to 0.3 ).

Based on our study, the micro-enterprises had the most problems receiving financial support from the EU funds. This proves our H2 in general. A description of the direction of this change follows. According to assessment of the representatives of micro-, small and medium enterprises, the financial support from the different sources contributed to an increase in the quality of the improved product or service in the eyes of customers, the rank of an improved product or service, among other company products, the company's share in the market, and a moderate increase in work standards and safety (see Table 2). Most of representatives of micro-enterprises known these results, but only $32 \%$ of them had seen the increase in work standards, $30 \%$ the growth of work safety, $26 \%$ the growth of production flexibility, $20 \%$ creation of new jobs, and $13 \%$ developed new sources of supply that are at a statistical significance level.

Tab. 2 - The economic results of enterprises with financial support (evaluation by managers, number and \%). Source: own research

\begin{tabular}{|l|l|l|l|l|l|l|}
\hline \multirow{2}{*}{ Economic results } & \multicolumn{2}{|l|}{$\begin{array}{l}\text { Micro-enter- } \\
\text { prises }\end{array}$} & \multicolumn{2}{l|}{ Small enterprises } & \multicolumn{2}{l|}{$\begin{array}{l}\text { Medium enter- } \\
\text { prises }\end{array}$} \\
\cline { 2 - 8 } & $\begin{array}{l}\text { Number } \\
\text { of replies }\end{array}$ & $\%$ & $\begin{array}{l}\text { Number } \\
\text { of replies }\end{array}$ & $\%$ & $\begin{array}{l}\text { Number } \\
\text { of replies }\end{array}$ & $\%$ \\
\hline $\begin{array}{l}\text { The growth of the rank of an im- } \\
\text { proved product or service among } \\
\text { other company products }\end{array}$ & 59 & 53.8 & 29 & 63.4 & 34 & 62.2 \\
\hline
\end{tabular}




\begin{tabular}{|c|c|c|c|c|c|c|}
\hline $\begin{array}{l}\text { The growth of the prices of } \\
\text { products and services as a result of } \\
\text { depreciation costs of new equip- } \\
\text { ment }\end{array}$ & 30 & 28.0 & 15 & 34.1 & 23 & 42.2 \\
\hline $\begin{array}{l}\text { Improving the quality of the } \\
\text { improved product or service in the } \\
\text { eyes of customers }\end{array}$ & 62 & 57.0 & 23 & 51.2 & 38 & 68.9 \\
\hline $\begin{array}{l}\text { The growth of the company's share } \\
\text { in the market }\end{array}$ & 54 & $49 ., 5$ & 22 & 48.8 & 35 & 64.4 \\
\hline $\begin{array}{l}\text { The decrease of the company's } \\
\text { share in the market }\end{array}$ & 8 & 7.5 & 4 & 8.5 & 1 & 2.2 \\
\hline The company gained a new market & 36 & 33.3 & 12 & 26.8 & 27 & 48.9 \\
\hline Improving production flexibility & 28 & 25.8 & 16 & 35.4 & 28 & 51.1 \\
\hline Improving production efficiency & 34 & 31.2 & 17 & 37.8 & 28 & 51.1 \\
\hline Labor costs per product reduction & 22 & 20.4 & 12 & 26.8 & 18 & 33.3 \\
\hline $\begin{array}{l}\text { The amount of materials and en- } \\
\text { ergy per product reduction }\end{array}$ & 15 & 14.0 & 7 & 15.9 & 13 & 24.4 \\
\hline The growth of the operating costs & 26 & 23.7 & 10 & 23.2 & 22 & 40.0 \\
\hline $\begin{array}{l}\text { New sources of supply were de- } \\
\text { veloped }\end{array}$ & 14 & 12.9 & 9 & 19.5 & 17 & 31.1 \\
\hline $\begin{array}{l}\text { The existing suppliers have not } \\
\text { adapted to new or changed materi- } \\
\text { als and services }\end{array}$ & 6 & 5.4 & 3 & 7.3 & 9 & 15.6 \\
\hline $\begin{array}{l}\text { New market structures were cre- } \\
\text { ated }\end{array}$ & 9 & 8.6 & 4 & 8.5 & 11 & 20.0 \\
\hline $\begin{array}{l}\text { The company's harmful impact on } \\
\text { health and the environment was } \\
\text { reduced }\end{array}$ & 19 & 17.2 & 7 & 15.9 & 17 & 31.1 \\
\hline The increase in work safety & 33 & 30.1 & 12 & 26.8 & 28 & 51.1 \\
\hline The increase in work standards & 35 & 32.3 & 12 & 25.6 & 37 & 66.7 \\
\hline Creation of new jobs & 22 & 20.4 & 17 & 36.6 & 34 & 62.2 \\
\hline Total: number / \% & $N=569$ & $0.0^{*}$ & $N=256$ & $0.0^{*}$ & $\mathrm{~N}=447$ & $0.0^{*}$ \\
\hline
\end{tabular}

* The total sum of percentage points is greater than 100 because each entrepreneur could assess many positions in the questionnaire. ${ }^{* *}$ The economic effects with a level of statistical significance have been highlighted in bold.

The representatives of small-sized enterprises repeated the positive economic effects like the representatives of micro-enterprises; however, their effects were moderately higher. At a statistical significance level, economic effects were not just production flexibility improvement $(35 \%)$, work safety growth $(27 \%)$, and work standards growth $(26 \%)$. The financial support, especially from the Structural Funds and bank loans, has led to job creation (37\%) and new supply sources $(19 \%)$. 
Economic results such as the creation of new market structures, reduction of labor costs, improved production efficiency, new market gains, growth of the company's share in the market, improvement of the quality of a product or service in the eyes of customers stay below at a statistical significance level. Although the financial support aided SMEs in improving their economic indicators, these indicators are unlikely to increase their competitiveness. Moreover, the enterprises that have experienced an increase in work standards and safety, and growth of production flexibility, cannot expect an immediate increase in their competitiveness.

The owners and the managers of medium-sized businesses were the most optimistic in comparison with representatives of micro- and small enterprises. According to them, financial support affected the creation of new jobs $(62 \%)$, production flexibility growth $(51 \%)$, work safety growth (51\%), work standards growth (67\%), and development of new supply sources $(31 \%)$. Representatives of medium-sized enterprises confirm the opinions of owners of micro and small enterprises. This is similar to the findings of Asdrubali \& Signore (2015), who indicate an estimated increase in employment, as a result of EU support, of 14\%-18\%. Economic effects that are related to investment in innovations that lead to sustainable economic development and SME competitiveness (i.e., growth of production efficiency, the creation of new market structures, growth in market share, and the reduction of the company's harmful impact on health and the environment) stayed below at a statistical significance level in managers' opinion.

Assessment of economic effects of SMEs without financial support is different as they have a much higher number of economic results, which are at the level of statistical significance, and they can lead to improving competitiveness and sustainable development (see Table 3).

Tab. 3 - The economic results of enterprises without financial support (evaluation of managers, number and \%). Source: own research

\begin{tabular}{|l|l|l|l|l|l|l|}
\hline \multirow{2}{*}{ Economic results } & \multicolumn{2}{|l|}{ Micro-enterprises } & \multicolumn{2}{l|}{ Small enterprises } & \multicolumn{2}{l|}{$\begin{array}{l}\text { Medium } \\
\text { enterprises }\end{array}$} \\
\cline { 2 - 8 } & $\begin{array}{l}\text { Number of } \\
\text { replies }\end{array}$ & $\%$ & $\begin{array}{l}\text { Number of } \\
\text { replies }\end{array}$ & $\%$ & $\begin{array}{l}\text { Number of } \\
\text { replies }\end{array}$ & $\%$ \\
\hline $\begin{array}{l}\text { The growth of the rank of an } \\
\text { improved product or ser- } \\
\text { vice among other company } \\
\text { products }\end{array}$ & 139 & 35.8 & 31 & 37.0 & 72 & 58.4 \\
\hline $\begin{array}{l}\text { The growth of the prices of } \\
\text { products and services as a } \\
\text { result of depreciation costs of } \\
\text { new equipment }\end{array}$ & 88 & 22.6 & 18 & 21.4 & 61 & 49.5 \\
\hline $\begin{array}{l}\text { Improving the quality of the } \\
\text { improved product or service } \\
\text { in the eyes of customers }\end{array}$ & 128 & 32.8 & 29 & 34,4 & 76 & 61.4 \\
\hline $\begin{array}{l}\text { The growth of the company's } \\
\text { share in the market }\end{array}$ & 111 & 28.6 & 25 & 29.9 & 78 & 63.4 \\
\hline
\end{tabular}




\begin{tabular}{|c|c|c|c|c|c|c|}
\hline $\begin{array}{l}\text { The decrease of the company's } \\
\text { share in the market }\end{array}$ & 47 & 12.0 & 2 & 1.9 & 6 & 5.0 \\
\hline $\begin{array}{l}\text { The company gained a new } \\
\text { market }\end{array}$ & 69 & 17.8 & 19 & 22.1 & 52 & 42.6 \\
\hline $\begin{array}{l}\text { Improving production flex- } \\
\text { ibility }\end{array}$ & 64 & 16.6 & 21 & 25.3 & 48 & 38.6 \\
\hline $\begin{array}{l}\text { Improving production ef- } \\
\text { ficiency }\end{array}$ & 68 & 17.5 & 21 & 24.7 & 52 & 42.6 \\
\hline $\begin{array}{l}\text { Labor costs per product } \\
\text { reduction }\end{array}$ & 41 & 10.5 & 16 & 18.8 & 35 & 28.7 \\
\hline $\begin{array}{l}\text { The amount of materials and } \\
\text { energy per product reduction }\end{array}$ & 32 & 8.1 & 8 & 9.1 & 32 & 25.7 \\
\hline $\begin{array}{l}\text { The growth of the operating } \\
\text { costs }\end{array}$ & 66 & 16.9 & 13 & 15.6 & 54 & 43.6 \\
\hline $\begin{array}{l}\text { New sources of supply were } \\
\text { developed }\end{array}$ & 46 & 11.7 & 14 & 16.9 & 33 & 26.7 \\
\hline $\begin{array}{l}\text { The existing suppliers } \\
\text { have not adapted to new } \\
\text { or changed materials and } \\
\text { services }\end{array}$ & 18 & 4.5 & 3 & 3.9 & 7 & 5.9 \\
\hline $\begin{array}{l}\text { New market structures were } \\
\text { created }\end{array}$ & 22 & 5.7 & 10 & 11.7 & 32 & 25.7 \\
\hline $\begin{array}{l}\text { The company's harmful } \\
\text { impact on health and the envi- } \\
\text { ronment was reduced }\end{array}$ & 29 & 7.5 & 7 & 7.8 & 32 & 25.7 \\
\hline $\begin{array}{l}\text { The increase of the work } \\
\text { safety }\end{array}$ & 83 & 21.4 & 20 & 23.4 & 56 & 45.5 \\
\hline $\begin{array}{l}\text { The increase in work stan- } \\
\text { dards }\end{array}$ & 118 & 30.4 & 30 & 35.1 & 74 & 60.4 \\
\hline Creation of new jobs & 57 & 14.8 & 23 & 27.3 & 56 & 45.5 \\
\hline Total: number / \% & $\mathrm{N}=1449$ & $0.0^{*}$ & $\mathrm{~N}=338$ & $0.0^{*}$ & $\mathrm{~N}=934$ & $0.0^{*}$ \\
\hline
\end{tabular}

* The total sum of percentage points is greater than 100 due to the fact that each entrepreneur was able to assess numerous positions in the questionnaire. ${ }^{* *}$ The economic effects with a level of statistical significance have been highlighted in grey colour.

Some of the SMEs with financial support did not achieve economic profit as a result of the investment in innovations in direct contrast to the enterprises with no financial support that did achieve such profits. According to the survey results of the owners, micro-enterprises in the period 2004-2013 either increased the rank of an improved product or service among other company products $(36 \%)$, improved the rank of an improved product or service among other company products $(36 \%)$, increased the quality of the improved product or service in the eyes of customers (33\%), increased the company's share in the market (29\%), increased work standards $(30 \%)$ and work safety $(21 \%)$, gained a new market $(18 \%)$, increased the production efficiency 
$(18 \%)$ and production flexibility (17\%), created new jobs (15\%), and / or developed new sources of supply $(12 \%)$. Small businesses showed better results.

Unlike the owners and managers of micro- and small businesses, the medium-sized businesses surveyed more often perceived job creation (46\%), increased production efficiency (43\%) and production flexibility (39\%), reducing labor costs per product $(29 \%)$, increase in the company's share in the market $(63 \%)$, development of new sources of supply $(27 \%)$, and / or creation of new market structures (26\%) as one or more of the most significant effects. Most of the economic results at a statistical significance level have the character of stimulating SME competitiveness. The economic effects that remained below a statistical significance level are as follows: dismissal of some employees, growth of the company's harm to health and the environment, decrease in revenues due to the crowding out of the existing company products from the market, and growth of the company's harmful impact on health and the environment. Most of these factors reduced the competitiveness of the SMEs. It should be noted that overall medium-sized companies were shown to use financial support more effectively than micro- and small companies.

Interestingly, the small enterprises that obtained financial support showed similar results as did small companies without financial support. The case of medium-sized companies was similar. A significant finding is that the supported enterprises (especially micro-enterprises) less often achieved effects improving their competitiveness and contributions to sustainable development, which is consistent with the vision of the EU funds.

A literature review indicates clear differences in the assessment of the effectiveness of the structural funds. Bachtler \& Gorzelak (2007) pointed to the widening of differences between regions, a similar conclusion reached in other research (Misiag et al., 2013). These differences persist in EU regions and countries. In examining the effectiveness of the use of the amount of EU support in Poland, Misiag et al. (2013) indicated that the main choices made in the allocation of EU funds for Eastern Poland regions did not provide the planned acceleration of economic growth in these regions. These regions did not begin the process of "catching up" with the rest of the country (Polish Agency for Enterprise Development, 2016). Poland is not converging with the developed EU countries in terms of innovation transfer nor in the development of new technologies and a knowledge-based economy. A large number of EU countries have shown limited innovation capabilities. This result supports the arguments of other authors (European Commission, 2016). Čadil et al. (2017) have examined how public support (the Operational Programme Enterprise and Innovations for Competitiveness [OPEIC] of European Structural Funds from 2007-2013) influence the competitiveness of SMEs. According to this study, the European Structural Funds project seems merely as a short-term fiscal policy that temporarily creates jobs rather than a policy that focuses on driving competitiveness and promoting long term economic growth.

We have observed small businesses as the least successful in drawing financial support from the Structural Funds. According to Lewandowska et al. (2019), EU Structural Funds are perceived as a supplementary source of financing for development, a perception which seems due to how the projects were financed. The support was available only for established enterprises, i.e. for stronger and bigger firms that already possessed good financial conditions and a solid market position. One of the probable reasons for this is that small and especially micro-enterprises have 
limited innovation capacity. In general micro-enterprises are not be able to generate adequate capital to invest in long-term actions such as $\mathrm{R}+\mathrm{D}+\mathrm{I}$, innovation transfer, ICT, intellectual property protection, the implementation of new solutions, etc. Thus micro-enterprises and sometimes small enterprises do not possess the suitable potential and resources for achieving basic economic effects, much less the ability to secure sustainable development and improve long term competitiveness (Vojtovič, 2016).

To successfully use EU funds, a well-developed system for the drawing of financial support is necessary as well as an appropriate form of financial support suitable for the expectations of the business. Examining the effectiveness of the use of the amount of EU support in Poland, Misiag et al. (2013) showed that the distribution of a significant part of public funds is carried out according to the principles unconducive to the optimal allocation goals or results.

Among the probable reasons for the low efficiency of the use of EU funds in Poland, Misiag et al. (2013) indicate the following: the incompatibility of the implemented strategy for the use of the European funds with the formally declared goals of development policy, insufficient care for the economic and effective use of the European funds in individual projects financed with the European funds, the less favorable external conditions in which projects were implemented through the policies of recent years as well as delays in the implementation of projects supported by the European funds. In our opinion, enterprises continue to lack a strategy in the direction of sustainable economic growth. Poland still remains to a degree outside the competitive and knowledge-based global economy and also lacks managerial skill. The Polish economy still is largely guided by a conservative approach.

\section{CONCLUSION}

The SME sector in the European Union is considered to be the main force promoting industrial competitiveness. Activities stimulating entrepreneurship, supporting the development of SMEs, and / or creating a favorable investment climate encourage the growth of the region's competitiveness. However, more money and good intentions are not sufficient to fight the slow development of SMEs. Institutions and companies need reliable data on the efficiency of financial instruments. Therefore, both EU institutions and the individual EU countries require reliable information on the effects of the current policy regarding SMEs.

Small and medium-sized enterprises are engaging more and more often in innovative activities through which they can achieve many economic benefits. Above all, these businesses can remain on the market and compete with other entities by focusing on various types of improvements and new products. Debates regarding the effectiveness of financial instruments and funding show no signs of ending any time soon. Studies on the effectiveness of the mechanisms and instruments on the convergence process have presented mixed findings. In addition, empirical work addressing company-level assessments of funding effects is scarce. We have presented one case study of a country under the innovation-stimulating policy. The research was conducted in Poland, a nation that thirty years ago was not only poor but also dormant in terms of innovation, but that has now begun to engage in specific activities to this end. Based on the analysis of macroeconomic data and analysis of microeconomic (quantity and quality), our assessment indicates an inefficient use 
of financial support from EU funds. This concerns both the objectives of these funds as well as the conditions for their allocation and redistribution.

The study evaluated the efficiency of financial support from the EU funds based on assessing the owners or managers of micro-, small and middle-sized companies. The authors hypothesized that financial support for innovation investments is ineffectively used by SMEs (H1). In this regard, although it has been shown that on a global scale the existing support from the EU funds has been hardly noticeable, it remains a significant factor regarding innovativeness on the scale of the micro-single enterprise. According to the results from the business owners and managers of micro-, small and middle-sized companies surveyed, the economic effects of enterprises with financial support are similar or even a bit worse than the companies that did not receive the financial support. The study results confirmed that the companies with financial support did not achieve such economic effects that would lead to their sustainable development or competitiveness. This support often has a demand-driven effect, but it does not improve firm competitiveness.

The hypothesis was confirmed that the effective results from the financial support of EU funds varies with the size of the enterprise (H2). The results of this study show that microenterprises were the least effective in the use of financial support from EU funds. The analyses of the objectives and criteria of the support granted to entrepreneurs indicate that micro- and small companies have neither adequate resources nor the potential for efficient use of received financial support. Small businesses are also not very efficient in their use of the EU funds because of the lack of a long-term strategy in sustainable economic growth as well as a lack of competitiveness and participation in the knowledge-based global economy. The big question is whether to support future action in all enterprises or only in those developing enterprises. The results of this study may provide begin to provide substantial scientific evidence for the use of institutions involved in SMEs, including for academic purposes, the private sector as well as other agencies involved in business development.

Our study has addressed several crucial and problematic issues, but still has some limitations that could be improved in future research, including the selection of measures for the research tool. Effectiveness and efficiency measurement methods are numerous, and future research could also be extended by employing other instruments and investigating other regions and/or countries. Future surveys should be further developed by estimating the net efficiency of the financial innovation support used within the framework of the European Union's policy on SMEs (not only European structural funds). In addition, future studies should include comparisons of regions or countries to bridge the numerous information gaps.

\section{References}

1. Asdrubali, P., \& Signore, S. (2015) The economic impact of EU guarantees on credit to SMEs. European Economy Discussion Papers, no. 2. Brussels: European Commission.

2. Audretsch, D. B., Coad, A., \& Segarra, A. (2014). Firm growth and innovation. Small Business Economics, 43 (4), 743-749. https://doi.org/10.1007/s11187-014-9560-x 
3. Bachtler, J., \& McMaster, I. (2008). EU Cohesion Policy and the Role of the Regions: Investigating the Influence of Structural Funds in the New Member States. Environment and Planning C: Government and Policy, 26 (2), 398-427. https://doi.org/10.1068/c0662

4. Bachtler, J., \& Gorzelak, G. (2007). Reforming EU cohesion policy: a reappraisal of the performance of the Structural Funds. Policy Studies, 28 (4), 309-326. http://dx.doi. org/10.1080/01442870701640682

5. Bednář, P., \& Halásková, M. (2018). Innovation performance and R\&D expenditures in Western European regions: Divergence or convergence? Journal of International Studies, 11 (1), 210-224. https://doi.org/10.14254/2071-8330.2018/11-1/16

6. Berkowitz, P., Monfort, P., \& Pieńkowski, J. (2020). Unpacking the growth impacts of European Union Cohesion Policy: transmission channels from Cohesion Policy into economic growth. Regional Studies, 54 (1), 60-71. https://doi.org/10.1080/00343404.2019.1570491

7. Bernini, C., \& Pellegrini, G. (2011). How are growth and productivity in private firms affected by public subsidy? Evidence from a regional policy. Regional Science and Urban Economics, 41 (3), 253-265. https://doi.org/10.1016/j.regsciurbeco.2011.01.005

8. Bilan Y., Mishchuk, H., Roshchyk, I. \& Joshi, O. (2020). Hiring and retaining skilled employees in SMEs: problems in human resource practices and links with organizational success. Business: Theory and Practice, 21 (2), 780-791. https://doi.org/10.3846/btp.2020.12750

9. Bondonio, D. (2014). Revitalizing regional economies through enterprise support policies: an impact evaluation of multiple instruments. European Urban \& Regional Studies, 21 (1), 79-103. https://doi.org/10.1177/0969776411432986

10. Braja, M., \& Gemzik-Salwach, A. (2019). Competitiveness of high-tech sectors in the European Union: A comparative study. Journal of International Studies, 12 (2), 213-227. https:// doi.org/10.14254/2071-8330.2019/12-2/13

11. Čadil, J., Mirošník, K., \& Rehák, J. (2017). The lack of short-term impact of cohesion policy on the competitiveness of SMEs. International Small Business Journal: Researching Entrepreneurship, 35 (8), 991-1009. https://doi.org/10.1177/0266242617695382

12. Cera, G., Mlouk, A., Cera, E., \& Shumeli, A. (2020). The Impact of Entrepreneurship Education on Entrepreneurial Intention. A Quasi-Experimental Research Design. Journal of Competitiveness, 12 (1), 39- 56. https://doi.org/10.7441/joc.2020.01.03

13. Eckey, H., \& Türk, M. (2006). Convergence of EU-regions: A Literature Report. Discussion Paper at the Economic Department of the University of Kassel, 86 (6), Kassel.

14. European Commission. (2016). European Innovation Scoreboard 2016. Luxembourg: European Union Publications Office. Retrieved December 1, 2020, from https://www. knowledgetransferireland.com/Reports-Publications/European-Innovation-Scoreboard-2016. pdf

15. European Commission. (2010a). Europe 2020 Flagship Initiative Innovation Union, Communication from the Commission to the European Parliament, the Council, the European Economic and Social Committee and the Committee of the Regions, Brussels, COM (2010) 546 final of October 6, 2010. Retrieved December 1, 2020, from https:// ec.europa.eu/research/innovation-union/pdf/innovation-union-communication-brochure_ en.pdf 
16. European Commission. (2010b). Europe 2020 Strategy for smart, sustainable and inclusive growth, Communication from the Commission, Brussels, $\operatorname{COM}(2010) 2020$ final of March 3, 2010. Retrieved December 1, 2020, from https://ec.europa.eu/eu2020/pdf/COMPLET\%20 EN\%20BARROSO\%20\%20\%20007\%20-\%20Europe\%202020\%20-\%20EN\%20version.pdf

17. European Commission. (2008). "Think Small First" - A "Small Business Act" for Europe, Communication from the Commission to the Council, the European Parliament, the European Economic and Social Committee and the Committee of the Regions, Brussels, $\operatorname{COM}(2008) 394$ final of June 25, 2008. Retrieved December 1, 2020, from http://ec.europa. $\mathrm{eu} /$ growth/smes/business-friendly-environment/small-business-act/index_en.htm

18. Florio M., Vallino, E., \& Vignetti, S. (2017) How to Design Effective Strategies to Support SMEs Innovation and Growth During the Economic Crisis: Lessons from Ex-post Evaluation of 2007-2013 ERDF Programmes. European Structural \& Investment Funds Journal, 5 (2), 99-110. https://estif.lexxion.eu/article/ESTIF/2017/2/3

19. Galbraith, B., McAdam, R., Woods, J., \& McGowan, T. (2017). Putting policy into practice: an exploratory study of SME innovation support in a peripheral UK region. Entrepreneurship \& Regional Development, 29 (4), 668-691. https://doi.org/10.1080/08985626.2017.1325939

20. Hagen, T., \& Mohl, P. (2008). Which Is the Right Dose of EU Cohesion Policy for Economic Growth? ZEW Discussion Paper, 8(104). Retrieved November 23, 2020, from: http://193.196.11.222/pub/zew-docs/dp/dp08104.pdf

21. Ilyash, O., Dzhadan, I., \& Ostasz, G. (2018). The influence of the industry's innovation activities indices on the industrial products' revenue of Ukraine. Economics and Sociology, 11 (4), 317-331. https://doi.org/10.14254/2071-789X.2018/11-4/21

22. Juris R., Adamko P., \& Savov R. (2021) Innovation of Small and Medium-Sized Enterprises from the Perspective of Globalization. SHS Web of Conf., 92.07029. https://doi.org/10.1051/ shsconf/20219207029

23. Kokot-Stępień, P., \& Krawczyk, P. (2020). The impact of public support on innovative activity of enterprises. Ekonomia i Prawo. Economics and Law, 19 (2), 291-304. http://dx.doi. org/10.12775/EiP.2020.020

24. Leal Filho, W. \& Weresa M. (2007) Achieving Competitiveness Through Innovations - A Challenge for Poland and Other New EU Member States. Frankfurt am Main: Peter Lang Europäischer Verlag der Wissenschaften.

25. Lewandowska, A. (2021) Interactions between investments in innovation and SME competitiveness in peripheral regions. Polish case study. Journal of International Studies, 14 (1), 285-307. https://doi.org/10.14254/2071-8330.2021/14-1/20

26. Lewandowska, A., Pater, R., \& Cywiński, Ł. (2019). Determinants of business innovation in the Regional Innovation System context. Policy implications for a less developed region. Studia regionalne i lokalne, 1 (75), 5-27. https://doi.org/10.7366/1509499517501

27. Lolos, S. E. G., \& Sarantis E. G. (2009). The effect of EU structural funds on regional growth: assessing the evidence from Greece, 1990-2005. Economic Change \& Restructuring, 42 (3), 211-228. https://doi.org/10.1007/s10644-009-9070-z 
28. Melnikas, B. (2008). The knowledge-based economy in the European Union: innovations, networking and transformation strategies. Transformations In Business \& Economics, 7 (3), 170-192. http://www.transformations.knf.vu.lt/15c/article/know

29. Ministry of Regional Development (2011). Operational Programme 'Innovative economy' 2007-2013, Warsaw.

30. Misiąg, J., Misiąg, W., \& Tomalak, M. (2013). Ocena efektywności wykorzystania pomocy finansowej Unii Europejskiej jako instrumentu polityki spójności społeczno-gospodarczej oraz poprawy warunków życia. Rzeszów: WSIiZ z siedzibą w Rzeszowie. Retrieved December 1, 2020, from http://monitoruj.podkarpackie.pl/Grafika/Menu\%20boczne/Baza \%20wiedzy/ RAPORT_prof.\%20W.\%20Misi\%C4\%85g,\%20J.\%20Misi\%C4\%85g,\%20M.\%20Tomalak.pdf

31. Mohl, P. \& Hagen, T. (2010). Do EU structural funds promote regional growth? New evidence from various panel data approaches. Regional Science \& Urban Economics, 40 (5), 353-365. https://doi.org/10.1016/j.regsciurbeco.2010.03.005

32. Murzyn, D. (2020). Smart growth in less developed regions - the role of EU structural funds on the example of Poland. Innovation: The European Journal of Social Sciences, 33 (1), 96-113. https://doi.org/10.1080/13511610.2019.1611418

33. Nill, J., \& R. Kemp. (2009). Evolutionary Approaches for Sustainable Innovation Policies: from Niche to Paradigm? Research Policy 38 (4), 668-680. https://doi.org/10.1016/j. respol.2009.01.011

34. Oslo Manual: Proposed Guidelines for Collecting and Interpreting Technological Innovation Data. 3rd Edition. 2005. OECD, Eurostat. Retrieved February 20, 2017, http://www.oecd. org/dataoecd/35/61/2367580.pdf

35. Ministerstwo Gospodarki (2014). Przedsiębiorczość w Polsce, Warszawa. Retrieved February 20, 2017. Retrieved from: https://mg.gov.pl

36. Polish Agency for Enterprise Development. (2016). Raport o stanie sektora MSP w Polsce. Available online: https://www.parp.gov.pl/storage/publications/pdf/2016_raport_msp_pl_ clik.pdf, June 29, 2020.

37. Polska Agencja Rozwoju Przedsiębiorczości. (2011-2013). Global Entrepreneurship Monitor Report - Poland. Warszawa: Polska Agencja Rozwoju Przedsiębiorczości. Retrieved December 9, 2020, from https://www.gemconsortium.org/economy-profiles/poland-2

38. Polska Agencja Rozwoju Przedsiębiorczości. (1997-2013). Raport o stanie sektora małych i średnich przedsiębiorstw w Polsce (dla lat 1997-2013). Warszawa: Polska Agencja Rozwoju Przedsiębiorczości. https://www.parp.gov.pl/component/publications/ publications/?series=10\#filter-publications

39. Ramstad, E. (2009). Expanding Innovation System and Policy — an Organisational Perspective. Policy Studies, 30 (5), 533-553. https://doi.org/10.1080/01442870903208551

40. Vojtovič, S. (2016) The impact of the structural funds on competitiveness of small and medium-sized enterprises. Journal of Competitiveness, 8 (4), 30-45. https://doi.org/10.7441/ joc. 2016.04 .02 
41. Smith, H. L., \& Waters, R. (2011) Scientific Labour Markets, Networks and Regional Innovation Systems. Regional Studies, 45 (7), 961-976. https://doi.org/10.1080/00343404.2011. 557655

42. Squicciarini, M. (2017). Entrepreneurship, innovation and enterprise dynamics. Small Business Economics, 48 (2), 335-350. doi.org/10.1007/s11187-016-9784-Z

43. Tvaronaviciene, M., \& Burinskas, A. (2020). Industry 4.0 Significance to competition and the EU competition policy. Economics and Sociology, 13 (3), 244-258. https://doi.org/10.14254/2071789X.2020/13-3/15

44. Wojarska, M. (2016) EU cohesion policy funds in the context of sustainable development of polish regions. Research Papers of the Wroclaw University of Economics, 417, 185-195. https://doi. org/10.15611/pn.2016.417.18

\section{Contact information}

Assistant professor Anna Lewandowska, Ph.D.

University of Information Technology and Management

Poland

E-mail: alewandowska@wsiz.edu.pl

ORCID: 0000-0002-5351-8490

Associate professor Yuriy Bilan, Ph.D.

Tomas Bata University in Zlin

Crech Republic

E-mail:y.bilan@præ.edu.pl

ORCID:0000-0003-0268-009X

Associate professor Grzegorz Mentel, Ph.D.

Rzeszón University of Technology

Poland

E-mail:gmentel@prz.edu.pl

ORCID: 0000-0002-6371-1219 


\section{Appendix}

Tab. 4 - Chi-square and Crammer's V $\left(\phi_{c}\right)$ results for the data. Source: own research

\begin{tabular}{|c|c|c|c|c|}
\hline \multirow[t]{2}{*}{ Economic results } & \multicolumn{2}{|l|}{ Treated group } & \multicolumn{2}{|l|}{ Control group } \\
\hline & $\chi^{2}(\mathrm{df}, \mathrm{N})$ [p-value] & $\phi_{c}$ & $\chi^{2}(\mathrm{df}, \mathrm{N})$ [p-value] & $\phi_{c}$ \\
\hline $\begin{array}{l}\text { The growth of the rank of an improved product } \\
\text { or service among other company products }\end{array}$ & $\chi^{2}(4,210)=2.165[0.705]$ & 0.072 & $\chi^{2}(4,596)=21.791[0.000]$ & 0.135 \\
\hline $\begin{array}{l}\text { The growth of the prices of products and } \\
\text { services as a result of depreciation costs of new } \\
\text { equipment }\end{array}$ & $\chi^{2}(4,207)=3.588[0.465]$ & 0.093 & $\chi^{2}(4,597)=35.347[0.000]$ & 0.172 \\
\hline $\begin{array}{l}\text { Improving the quality of the improved product } \\
\text { or service in the eyes of customers }\end{array}$ & $\chi^{2}(4,209)=4.197[0.380]$ & 0.100 & $\chi^{2}(4,598)=34.805[0.000]$ & 0.171 \\
\hline $\begin{array}{l}\text { The growth of the company's share in the } \\
\text { market }\end{array}$ & $\chi^{2}(4,208)=5.118[0.275]$ & 0.111 & $\chi^{2}(4,596)=51.297[0.000]$ & 0.207 \\
\hline $\begin{array}{l}\text { The decrease of the company's share in the } \\
\text { market }\end{array}$ & $\chi^{2}(4,208)=4.901[0.298]$ & 0.109 & $\chi^{2}(4,597)=16.054[0.003]$ & 0.116 \\
\hline The company gained a new market & $\chi^{2}(4,208)=6.632[0.157]$ & 0.126 & $\chi^{2}(4,596)=31.411[0.000]$ & 0.162 \\
\hline Improving production flexibility & $\chi^{2}(4,208)=13.868[0.008]$ & 0.183 & $\chi^{2}(4,597)=29.814[0.000]$ & 0.158 \\
\hline Improving production efficiency & $\chi^{2}(4,209)=6.692[0.153]$ & 0.127 & $\chi^{2}(4,595)=34.435[0.000]$ & 0.170 \\
\hline Labor costs per product reduction & $\chi^{2}(4,209)=4.648[0.325]$ & 0.105 & $\chi^{2}(4,595)=34.143[0.000]$ & 0.169 \\
\hline $\begin{array}{l}\text { The amount of materials and energy per product } \\
\text { reduction }\end{array}$ & $\chi^{2}(4,208)=3.298[0.509]$ & 0.089 & $\chi^{2}(4,598)=31.515[0.000]$ & 0.162 \\
\hline The growth of the operating costs & $\chi^{2}(4,209)=5.755[0.218]$ & 0.117 & $\chi^{2}(4,597)=41.228[0.000]$ & 0.186 \\
\hline New sources of supply were developed & $\chi^{2}(4,209)=9.606[0.048]$ & 0.152 & $\chi^{2}(4,596)=17.033[0.002]$ & 0.120 \\
\hline $\begin{array}{l}\text { The existing suppliers have not adapted to new } \\
\text { or changed materials and services }\end{array}$ & $\chi^{2}(4,209)=11.147[0.025]$ & 0.163 & $\chi^{2}(4,596)=1.942[0.746]$ & 0.040 \\
\hline New market structures were created & $\chi^{2}(4,208)=7.113[0.130]$ & 0.131 & $\chi^{2}(4,597)=41.507[0.000]$ & 0.186 \\
\hline $\begin{array}{l}\text { The company's harmful impact on health and } \\
\text { the environment was reduced }\end{array}$ & $\chi^{2}(4,209)=7.737[0.102]$ & 0.136 & $\chi^{2}(4,596)=36.372[0.000]$ & 0.175 \\
\hline $\begin{array}{l}\text { The company's harmful impact on health and } \\
\text { the environment has increased }\end{array}$ & $\chi^{2}(4,209)=2.714[0.607]$ & 0.081 & $\chi^{2}(4,597)=4.318[0.365]$ & 0.060 \\
\hline The increase in work safety & $\chi^{2}(4,210)=10.810[0.029]$ & 0.160 & $\chi^{2}(4,596)=37.393[0.000]$ & 0.177 \\
\hline The increase in work standards & $\chi^{2}(4,211)=22.696[0.000]$ & 0.232 & $\chi^{2}(4,596)=37.054[0.000]$ & 0.176 \\
\hline Creation of new jobs & $\chi^{2}(4,209)=29.323[0.000]$ & 0.265 & $\chi^{2}(4,597)=52.006[0.000]$ & 0.209 \\
\hline
\end{tabular}

* Insignificant variables were removed from the table. 